\title{
Ant species (Hymenoptera: Formicidae) in the three forests of the Ischigualasto Provincial Park, a protected area of the Monte Desert, Argentina
}

\author{
EMILCE AMATTA ${ }^{1,2, \vartheta}$, LUIS A. CALCATERRA ${ }^{4,5}$, STELLA M. GIANNONI ${ }^{1,2,3, \vee \vartheta}$ \\ ${ }^{1}$ Centro de Investigación de la Geósfera y la Biósfera, Universidad Nacional de San Juan-Consejo Nacional de Investigaciones Científicas y Técnicas, \\ Facultad de Ciencias Exactas, Físicas y Naturales, Complejo Universitario Islas Malvinas, Ignacio de la Roza 590 (Oeste), Rivadavia (J5402DCS), San \\ Juan, Argentina. Tel.: +54-264-4260353, Fax.: +54-2644234980, `email: emilceamatta@unsj-cuim.edu.ar; "` sgiannoni@unsj-cuim.edu.ar \\ ${ }^{2}$ Departamento de Biología, Facultad de Ciencias Exactas, Físicas y Naturales, Universidad Nacional de San Juan, San Juan, Argentina \\ ${ }^{3}$ Instituto y Museo de Ciencias Naturales, Facultad de Ciencias Exactas, Físicas y Naturales, Universidad Nacional de San Juan San Juan, Argentina \\ ${ }^{4}$ Fundación para el Estudio de Especies Invasivas (FuEDEI), Buenos Aires, Argentina \\ ${ }^{5}$ Consejo Nacional de Investigaciones Científicas y Técnicas (CONICET), Buenos Aires, Argentina
}

Manuscript received: 7 February 2018. Revision accepted: 17 April 2018

\begin{abstract}
Amatta E, Calcaterra LA, Giannoni SM. 2018. Ant species (Hymenoptera: Formicidae) in the three forests of the Ischigualasto Provincial Park, a protected area of the Monte Desert, Argentina. Biodiversitas 19: 831-839. Deforestation and overgrazing mediated by the humans have caused a serious process of desertification in the Argentine Monte Desert, which threats biodiversity of this ecosystem. Forests provide important resources and refuge for animal species, such as ants. The objective of this work was to survey the ant fauna of dryland forests of Ischigualasto Provincial Park, a protected area located in the hyper-arid Monte Desert ecoregion in the province of San Juan, Argentina. Ant species were surveyed in summer in three types of forests (Prosopis, Ramorinoa and Bulnesia forests), using a combination of sampling methods: pitfall-traps, baiting, and hand collection. A total of 33 ant species were collected, of which 17 are new records for the Monte Desert and Dry Chaco and 24 for the San Juan province. The species richness is within the range reported for other Argentine desert and semi-desert areas. Prosopis forest was the richest with 32 species (24 exclusive), followed by Ramorinoa and Bulnesia forests with 11 and 4 species, respectively. This study contributes to improve the knowledge of ant fauna in desert habitats of the world, especially those inhabiting Prosopis forests, which are the most important ant diversity hotspots within the hyper-arid desert.
\end{abstract}

Keywords: Arid land, desert' biodiversity, Formicidae, native forests, ant richness

\section{INTRODUCTION}

Ants are ecologically significant invertebrates in many forest ecosystems that constitute up to $95 \%$ of animal biomass (Moffett 2012), perform important ecological functions (Ginzburg et al. 2008, Whitford et al. 2008) and they are also involved in diverse animal-plant interactions (Hölldobler and Wilson 1990, Chacoff and Aschero 2014).

Arid zones support fewer ant species in comparison to tropical terrestrial ecosystems (Rojas and Fragoso 2000). However, ants are still abundant and conspicuous components of arid ecosystems due to the biomass they represent compared to other taxa (MacKay 1991). Deserts have harsh environmental conditions, which are characterized by high solar radiation, pronounced temperature fluctuations and scarce humidity (Whitford 2002). These environmental conditions impose severe restrictions that limit the distribution, establishment and, consequently, richness and abundance of ants (PérezSánchez et al. 2012). In desert areas, forests are important habitat components because they provide critical resources and refuge for ants (Bestelmeyer and Schooley 1999). Trees offer suitable foraging and nesting sites, creating appropriate microclimates under their canopies, a layer of litter on the soil surface (Bestelmeyer 1997), floral and extra-floral nectaries, and fruits that provide food resources to several omnivorous ant species among other resources (Fuster 2012).

Arid and semiarid lands represent $75 \%$ of the total area of Argentina (Cabrera and Willink 1980). Ischigualasto Provincial Park is a protected area located in the hyper-arid part of the Monte of mountains and basins ecoregion (Márquez et al. 2005). This ecoregion has a complex topographic relief accompanied by a diverse mosaic of habitats (Burkart et al. 1999), physiognomically characterized by shrubs and forests dominated by Prosopis flexuosa DC and P. chilensis (Molina) Stuntz. emend Burkart (Leguminosae). In this arid environment, Prosopis species are key components because they create favourable microhabitats that support plant and animal species that do not occur in other microhabitats (Campos and Velez 2015). Ramorinoa girolae Speg. (Fabaceae) and Bulnesia retama Gillies ex Hook. \& Arn (Zygophillaceae) are two other important trees of this ecoregion.

Trees of this ecoregion have high ecological value due to the biological interactions established within their communities, therefore, they represent a concern for conservation. Prosopis has an important role in providing shade, protection and food for animals and plants (Perosa et al. 2014). However, in spite of its relevance, it is the most 
threatened forest because of heavy logging (Villagra et al. 2009). R. gorilae is ranked as vulnerable due to its restricted geographical distribution, poor fire resistance and monotypic nature (Demaio et al. 2002). This forest has many important functions such as slope stabilization, erosion control, and as a harbor for high diversity of plants and fauna (Campos et al. 2017). B. retama has an important role protecting soils and its associated flora and fauna (Dalmasso and Llera 1996). Continuous extraction of wood from $B$. retama trees for vineyard posts as well as intensive pruning for wax production have greatly diminished their natural populations (Dalmasso and Llera 1996).

In spite of the importance of these forests in dryland, there is scarce information about the arthropod species occurring in them. Local inventories of the Argentine ant fauna are concentrated in wetter areas (Calcaterra et al. 2010, Hanisch et al. 2015), while ant assemblages from most arid zones remain unknown. This lack of information represents a concern since deserts are part of vulnerable ecosystems (Assessment Millennium Ecosystem 2005).

The objective of this study was to survey the ant fauna occurring in the dryland forests of Ischigualasto Provincial Park. This study lists the ant species in the three forests of this protected area, and contributes to increase the knowledge of how these ants use the different microhabitats.

\section{MATERIALS AND METHODS}

\section{Study area}

This study was conducted in Ischigualasto Provincial Park (IPP) $\left(30^{\circ} 05^{\prime} \mathrm{S}, 67^{\circ} 55^{\prime} \mathrm{W}\right)$, a protected area located in the province of San Juan, Argentina (Figure 1). The park stretches from over 62,369 ha and has a mean altitude of 1,300 $\mathrm{m}$ above sea level. IPP and Talampaya National Park make up the Ischigualasto-Talampaya site, which was declared a World Heritage Site by UNESCO in 2000. The study area lies in the hyper-arid part of the Monte of mountains and basins ecoregion, and occupies a small portion of the Dry Chaco ecoregion (Brown et al. 2006). Overall plant cover is low (nearly 15\%), and the vegetation is dominated by Larrea and Atriplex spp. and four tree species: Prosopis chilensis and P. flexuosa, Ramorinoa girolae, and Bulnesia retama (Figure 2), as well as a low and seasonal herbaceous layer (Acebes et al. 2010). The forests occupy around $27 \%$ of the 62,369 ha (Márquez et al. 2005) of protected area. The $B$. retama forest is the largest in extent, covering $\sim 15 \%$ (9.300 ha), followed by the $R$. girolae forest $\sim 9 \%$ (5.600 ha) and the Prosopis spp. forest $\sim 3 \%$ (1.900 ha) of the park's land surface (Campos et al. 2016).

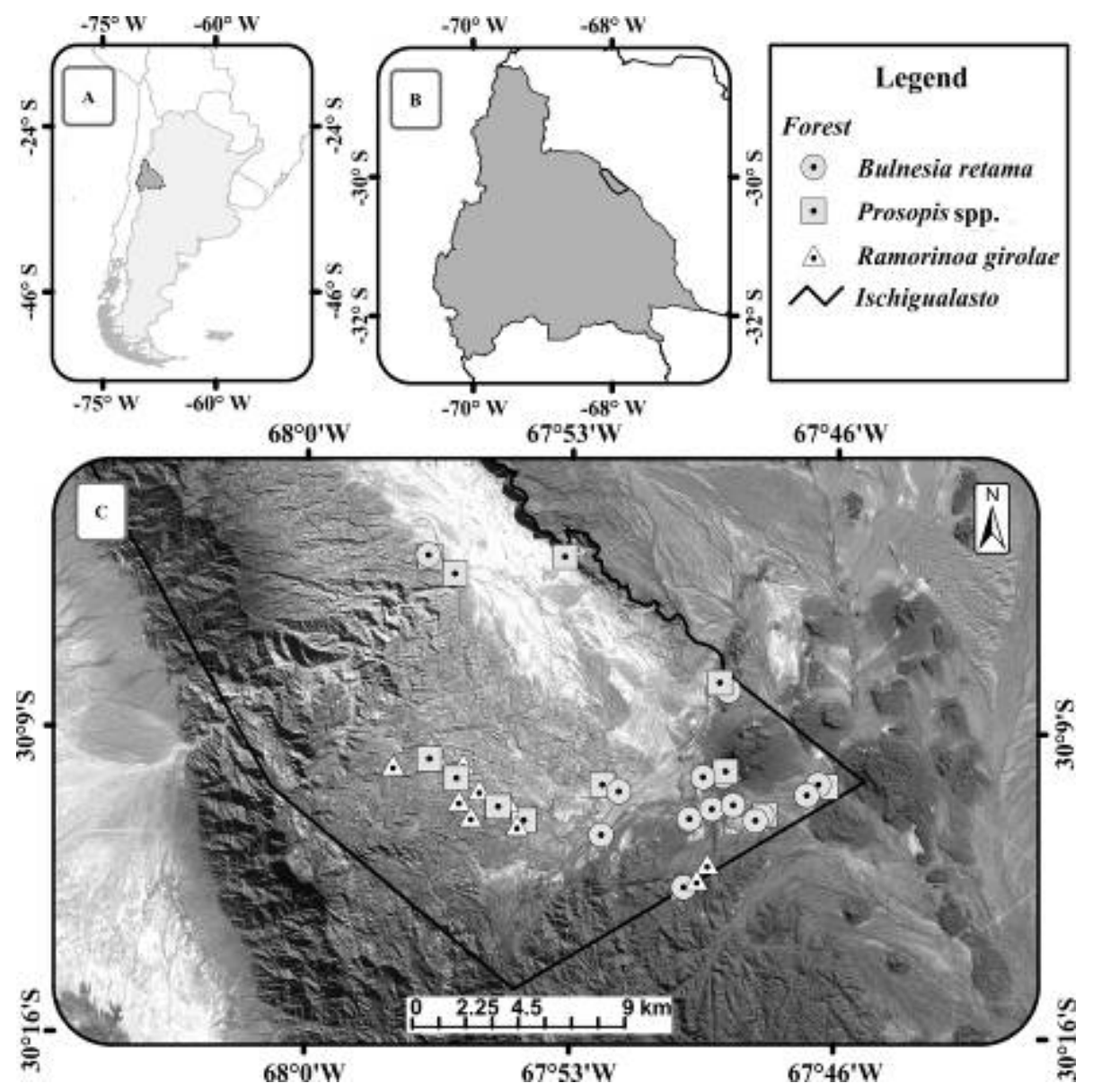

Figure 1. Map of Ischigualasto Provincial Park, San Juan, Argentina. Triangles, circles and squares indicate survey sites of each forest type. See text for a detailed description of the protected area. Reference frame POSGAR 07, GK 


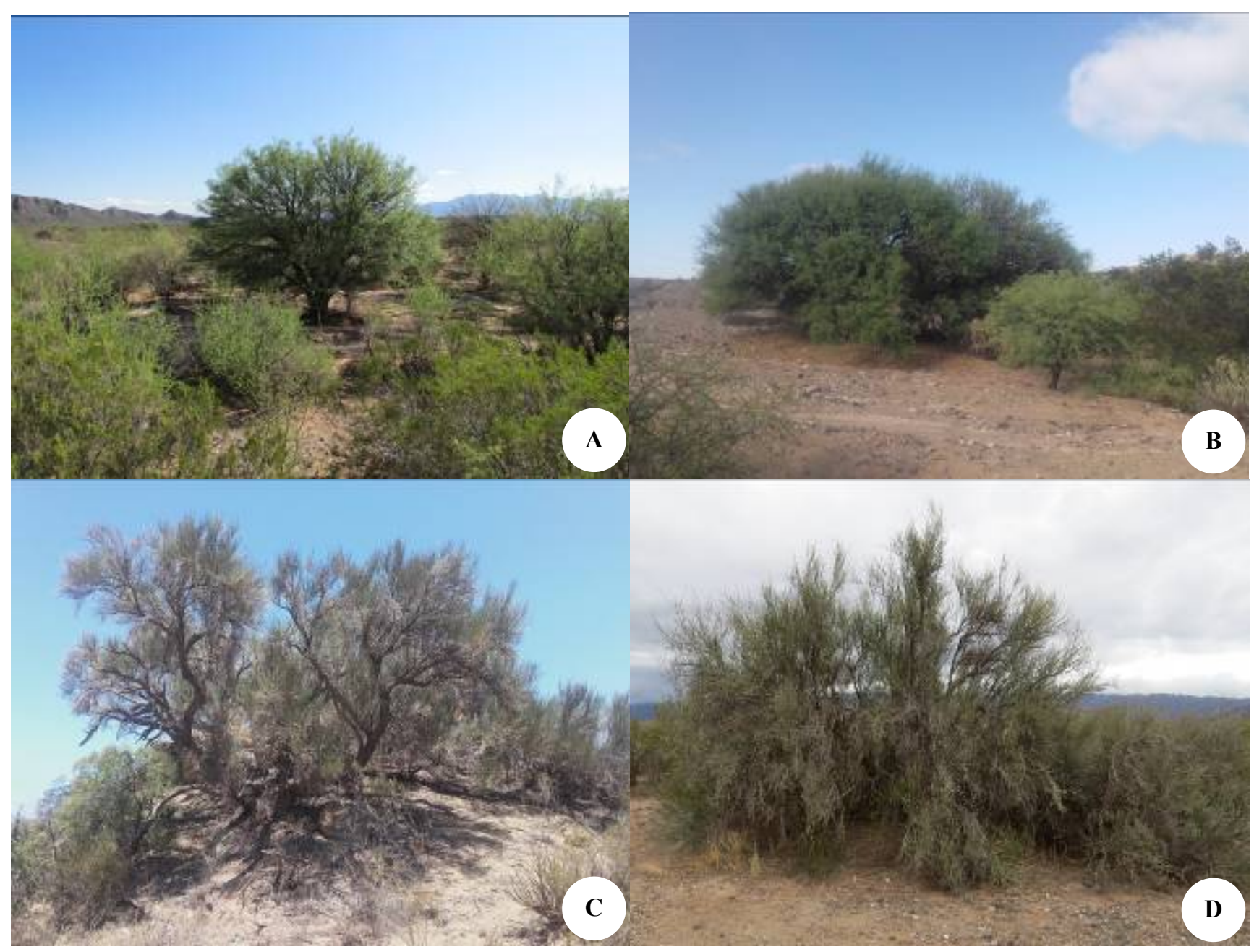

Figure 2. Trees of the Prosopis spp., Ramorinoa girolae and Bulnesia retama forests. A-B. The Prosopis forests which are trees with a mean height of $2.46 \mathrm{~m}$ tall, reaching a maximum height of $8.20 \mathrm{~m}$ (Campos et al. 2018). C. The $R$. girolae trees which have a mean height of $4.84 \mathrm{~m}$ (Campos et al. 2017) and can reach up to $6 \mathrm{~m}$ high (Marquez et al. 2005). D. The B. retama forests are trees with an average height of $1.60 \mathrm{~m}$ and can reach up to $3 \mathrm{~m}$ high (S. Giannoni, unpublished data). The Prosopis trees occupy around $\sim 49$ ind/ha, the $R$. girolae $\sim 33$ ind/ha and the $B$. retama the $\sim 11$ ind/ha (V. Campos, unpublished data).

The climate is arid with seasonal differences very marked. A mean annual precipitation of $100 \mathrm{~mm}$ (Labraga and Villalba 2009) concentrated in the warmest months (November-March) and averaging only $8 \mathrm{~mm}$ in the coldest months (April-October). Mean temperature in summer is $24.3^{\circ} \mathrm{C}$, with an absolute maximum of $45^{\circ} \mathrm{C}$ in January, whereas mean temperature in winter is $8.5^{\circ} \mathrm{C}$, with an absolute minimum of $-10^{\circ} \mathrm{C}$ in July (De Fina et al. 1962).

\section{Data collection}

Ant sampling was conducted from 9 a.m. to 8 p.m. during summer months of 2012 and 2013. Sampling was carried out at different points along the Prosopis spp., $R$. girolae, and B. retama forests (Figure 1). Ants were collected using a combination of pitfall-traps, baiting, and hand collecting methods. Sampling effort was approximately similar in the three forest types, resulting in a sampling effort of $260 \mathrm{~h}$ per forest (pitfall traps $=240 \mathrm{~h}$, baits $=10 \mathrm{~h}$, and manual collection $=10 \mathrm{~h}$ ). In each forest, we placed 10 pitfall-traps under tree's canopy during $24 \mathrm{~h}$ (separated $10 \mathrm{~m}$ from each other). Moreover, 20 baits in each forest were placed, separated by at least $1 \mathrm{~m}$ from each other, on the ground under trees, and on the trunks and branches. The baits consisted of $5 \times 5 \mathrm{~cm}$ pieces of paper with peanut butter on them, stations remained there for $30 \mathrm{~min}$, and all ant species attracted by them were collected. Three people performed manual gathering during $10 \mathrm{~h}$ in each forest. The ground beneath leaf litter, the trunks, the area under the bark of the trees and other surfaces were visually searched for ants at each sampling site. The total amount of time spent on visual searching was approximately $1 \mathrm{~h}$ in $R$. girolae trees, $50 \mathrm{~min}$ in Prosopis spp. trees and $42 \mathrm{~min}$ in $B$. retama trees. The time spent in each tree species varied based on the size and structural complexity of trees involved in the search. Microhabitats where ants were found were always recorded. 
The pitfall traps were plastic containers of $6 \mathrm{~cm}$ in diameter and $9 \mathrm{~cm}$ deep. Traps were filled to a depth of 3 $\mathrm{cm}$ with $70 \%$ solutions of an ethylene glycol/ethanol mixture as a preservative. Ants gather on the visual searches and with baits were collected, and preserved in $96 \%$ alcohol for their later identification in the laboratory under a dissecting microscope. Ants were initially identified to the genus level using available keys (Kusnezov 1978, Palacio and Fernández 2003) and then to the species level following Bolton (2013), genus keys and the help of specialists and photographic material available in Antweb page.

Ants were additionally assigned to functional groups following a classification adapted from Andersen (1995), Bestelmeyer and Wiens (1996), and field observations of behaviour on baits and available data on natural history of Argentine ant species, as in Calcaterra et al. (2010). Some groups defined by Bestelmeyer and Wiens (1996) for Argentine Chaco are exclusive to the Neotropical region (e.g. Attini) and have no correlations to Australian functional groups defined by Andersen (1995) and viceverse, some Australian functional groups are absent in Argentina (e.g. Dominant Dolichoderinae).

The voucher specimens were deposited in the ant fauna section of the Colección Entomológica IADIZA-CONICET in Mendoza, Argentina. Fieldwork was conducted under the research and collecting permit (expediente No. 13004004/2012) issued by Secretaría de Estado de Ambiente y Desarrollo Sustentable of San Juan, Argentina.

We employed generalized linear models (GLM) with Poisson error distribution (Crawley 2007) to evaluate the use of different microhabitats by ants in forests. The response variable used in the model was the richness of ants in each microhabitat. The statistical analyses were carried out using R Core Team (2017).

\section{RESULTS AND DISCUSSION}

\section{Results}

Thirty-three ant species belonging to four subfamilies and 13 genera were recorded in the three types of forests; including 30 new species for the IPP, 24 new species for San Juan Province, and 17 new species for the Monte of mountains and basins and Dry Chaco ecoregions (Table 1). Myrmicinae was the predominant subfamily with 19 species, followed by the Dolichoderinae subfamily with eight species, Formicinae with five species, and Dorylinae with only one species, whereas the richest genera were Camponotus, Dorymyrmex, Forelius, Pheidole, and Solenopsis with four species each (Table 1).

Prosopis spp. was the richest forest with 32 ant species ( $97 \%$ of the total species), followed by $R$. girolae forest with 11 species $(33 \%)$ and $B$. retama forest with four species (12\%); only Camponotus mus Roger, Camponotus punctulatus Mayr, Dorymyrmex ensinfer Forel, and Dorymyrmex planidens Mayr were recorded in all three forests (Table 1). Twenty-four species were exclusively collected in the Prosopis spp. forest, whereas Neivamyrmex diana (Forel) was only collected from the $R$. girolae forest; no exclusive species was collected in the $B$. retama forest.

Of the 33 species found, only 19 species were previously reported in four Monte Desert and Dry Chaco neighbouring areas (Table 2). The most represented functional groups were the hot-climate specialist (10 species), followed by Generalized myrmicine ( 8 species), Attini, Subordinate camponotini, and Arboreals (4 species each), and Cryptic, Army ants, and Opportunistic (1 species each) (Table 2).

Table 1. Checklist of ants found in the three types of forests in Ischigualasto Provincial Park, San Juan, Argentina

\begin{tabular}{|c|c|c|c|c|}
\hline \multirow[b]{2}{*}{ Species } & \multicolumn{3}{|c|}{ Forest } & \multirow[b]{2}{*}{$\begin{array}{l}\text { Voucher } \\
\text { code }\end{array}$} \\
\hline & 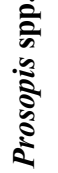 & 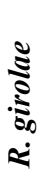 & 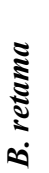 & \\
\hline
\end{tabular}

\section{Dolichoderinae}

Dorymyrmex ensifer Forel, 1912

Dorymyrmex exsanguis Forel, 1912

Dorymyrmex planidens Mayr, 1868

Dorymyrmex wolffhuegeli Forel, 1911*

Forelius albiventris Forel, 1912*

Forelius chalybaeus Emery, 1906*

Forelius nigriventris Forel, 1912*

Forelius rufus Gallardo, 1916*

$\begin{array}{llll}+ & + & + & \text { CEI-17497 } \\ + & - & - & \text { CEI-17498 } \\ + & + & + & \text { CEI-17499 } \\ + & - & - & \text { CEI-17500 } \\ + & - & - & \text { CEI-17501 } \\ + & - & - & \text { CEI-17502 } \\ + & - & - & \text { CEI-17503 } \\ + & & & \text { CEI-17504 }\end{array}$

\section{Dorylinae}

Neivamyrmex diana (Forel, 1912)* - $\quad+\quad$ - CEI-17505

\section{Formicinae}

Brachymyrmex patagonicus Mayr, 1868* Camponotus blandus (Smith, 1858)* Camponotus mus Roger, 1863

Camponotus substitutus Emery, 1894 Camponotus punctulatus Mayr, 1868

\section{Myrmicinae}

Acromyrmex lobicornis (Emery, 1888) Acromyrmex striatus (Roger, 1863) Cephalotes bruchi (Forel, 1912)*

Cephalotes liogaster (Santschi, 1916)* Cephalotes quadratus (Mayr, 1868)* Crematogaster rochai Forel, 1903* Crematogaster quadriformis Roger, 1863* Cyphomyrmex rimosus (Spinola, 1851)* Kalathomyrmex emeryi (Forel, 1907)* Pheidole aberrans Mayr, 1868*

Pheidole bergi Mayr, 1887

Pheidole triconstricta Forel, 1886*

Pheidole vafra Santschi, 1923*

Pogonomymex brevibarbis Emery, 1906*

Pogonomyrmex cunicularius Mayr, 1887* Solenopsis quinquecuspis Forel, 1913* Solenopsis interrupta Santschi, 1916* Solenopsis parva Mayr, 1868*

Solenopsis sp.*

$\begin{array}{rrrr}+ & + & - & \text { CEI-17506 } \\ + & + & - & \text { CEI-17507 } \\ + & - & + & \text { CEI-17508 } \\ + & - & - & \text { CEI-17509 } \\ + & + & + & \text { CEI-17510 }\end{array}$

Species richness per forest type Note: +: present, -: absent

\section{CEI-17511}

- CEI-17513

- CEI-17514

- CEI-17516

- CEI-17517

- CEI-17518

- CEI-17519

- CEI-17520

- CEI-17521

- CEI-17522

- CEI-17523

- CEI-17524

- CEI-17525

- CEI-17526

- CEI-17527

- CEI-17528

- CEI-17529

$\begin{array}{lll}32 & 11 & 4\end{array}$ $+\quad+\quad$ CEI-17512

- CEI-17515 
Table 2. Ant species collected in Ischigualasto Provincial Park, San Juan, Argentina (and their assignation to functional groups) and those species shared with other close studied areas: (I) Murúa et al. 1999, (II) Garcia and Quirán 2002, (III) Fuster 2012 and (IV) Claver et al. 2014

\begin{tabular}{llllll}
\hline $\begin{array}{l}\text { Subfamily } \\
\text { Species }\end{array}$ & \multicolumn{4}{c}{ Sites next to IPP } & Functional \\
\cline { 2 - 3 } & I & II & III & IV & group $^{\mathbf{a}}$ \\
\hline
\end{tabular}

\section{Dolichoderinae}

$\begin{array}{llllll}\text { Dorymyrmex ensifer } & + & - & - & - & \text { Hcs } \\ \text { Dorymyrmex exsanguis } & + & + & - & + & \text { Hcs } \\ \text { Dorymyrmex planidens } & + & + & - & - & \text { Hcs } \\ \text { Dorymyrmex wolffhuegeli } & - & + & - & + & \text { Hcs } \\ \text { Forelius albiventris } & - & - & - & - & \text { Hcs } \\ \text { Forelius chalybaeus } & - & + & - & + & \text { Hcs } \\ \text { Forelius nigriventris } & - & - & - & + & \text { Hcs } \\ \text { Forelius rufus } & - & - & - & - & \text { Hcs }\end{array}$

\section{Dorylinae}

Neivamyrmex diana

Aa

\section{Formicinae}

Brachymyrmex patagonicus - $\quad-\quad+\quad-\quad$ Op

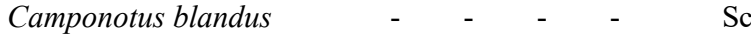

Camponotus mus $++\quad+\quad+\quad+\quad \mathrm{Sc}$

Camponotus substitutus $\quad+\quad-\quad-\quad-\quad-5 c$

Camponotus punctulatus $++++\quad \mathrm{Sc}$

\section{Myrmicinae}

Acromyrmex lobicornis

Acromyrmex striatus

Cephalotes bruchi

Cephalotes liogaster

Cephalotes quadratus

Crematogaster rochai

Crematogaster quadriformis

Cyphomyrmex rimosus

Kalathomyrmex emeryi

Pheidole aberrans

Pheidole bergi

Pheidole triconstricta

Pheidole vafra

Pogonomymex brevibarbis

Pogonomyrmex cunicularius

Solenopsis quinquecuspis

Solenopsis interrupta

Solenopsis parva

Solenopsis sp.

$$
\begin{array}{lllll}
\text { Shared species (total spp.) } & 9 & 11 & 5 & 11
\end{array}
$$

$$
\text { (19) (23) (16) (27) }
$$

Note: ${ }^{a}$ Functional groups: Sc, Subordinate camponotini; Gm, Generalized myrmicines; Op, Opportunists; At, Attini; Hcs, Hot climate specialists; Ar, Arboreals; Cr, Cryptics, and Aa, Army ants. +: present, -: absent
Table 3. Microhabitat used by each ant species in Prosopis spp., Ramorinoa girolae and Bulnesia retama forests of the

\begin{tabular}{|c|c|c|}
\hline Forest type & Ant species & Microhabitat used \\
\hline $\begin{array}{l}\text { Prosopis } \\
\text { spp. }\end{array}$ & $\begin{array}{l}\text { A. lobicornis } \\
\text { A. striatus } \\
\text { B. patagonicus } \\
\text { C. blandus } \\
\text { C. mus } \\
\text { C. punctulatus } \\
\text { C. substitutus } \\
\text { C. bruchi } \\
\text { C. liogaster } \\
\text { C. quadratus } \\
\text { C. quadriformis } \\
\text { C. rochai } \\
\text { C. rimosus } \\
\text { D. ensinfer } \\
\text { D. planidens } \\
\text { D. exsanguis } \\
\text { D. wolffhuegeli } \\
\text { F. albiventris } \\
\text { F. chalybaeus } \\
\text { F. nigriventris } \\
\text { F. rufus } \\
\text { K. emeryi } \\
\text { P. brevibarbis } \\
\text { P. cunicularius } \\
\text { P. bergi } \\
\text { P. aberrans } \\
\text { P. triconstricta } \\
\text { P. vafra } \\
\text { Solenopsis sp. } \\
\text { S. quinquecuspis } \\
\text { S. interrupta } \\
\text { S. parva }\end{array}$ & $\begin{array}{l}\text { Branches, leaves, fruits } \\
\text { Seeds, under canopy (above } \\
\text { ground) } \\
\text { Trunk bark, under canopy } \\
\text { Trunk bark (galls) } \\
\text { Trunk, fallen trees } \\
\text { Fruits, flowers } \\
\text { Within canopy } \\
\text { Trunk bark } \\
\text { Trunk bark } \\
\text { Trunk bark } \\
\text { Trunk bark } \\
\text { No data } \\
\text { Dry riverbed } \\
\text { Trunk bark (galls), branches, } \\
\text { leaves, fruits, under canopy } \\
\text { Trunk bark (galls), branches, } \\
\text { leaves, fruits, under canopy } \\
\text { Within canopy } \\
\text { No data } \\
\text { Within canopy } \\
\text { Within canopy } \\
\text { Within canopy } \\
\text { No data } \\
\text { No data } \\
\text { Seeds in feces } \\
\text { Under canopy } \\
\text { Trunk bark, under canopy } \\
\text { No data } \\
\text { No data } \\
\text { No data } \\
\text { Trunk bark, under canopy } \\
\text { No data } \\
\text { No data } \\
\text { No data }\end{array}$ \\
\hline R. girolae & $\begin{array}{l}\text { A. lobicornis } \\
\text { A. striatus } \\
\text { B. patagonicus } \\
\text { C. mus } \\
\text { C. punctulatus } \\
\text { C. quadriformis } \\
\text { D. ensinfer } \\
\text { D. planidens } \\
\text { P. bergi } \\
\text { Solenopsis } \mathrm{sp} \text {. } \\
\text { N. diana }\end{array}$ & $\begin{array}{l}\text { Trunk bark, under canopy } \\
\text { Trunk bark, under canopy } \\
\text { Trunk bark } \\
\text { Trunk bark, under canopy } \\
\text { Trunk bark, under canopy } \\
\text { Trunk bark, under canopy } \\
\text { Trunk bark } \\
\text { Trunk bark } \\
\text { Under canopy } \\
\text { Under canopy } \\
\text { No data }\end{array}$ \\
\hline B. retama & $\begin{array}{l}\text { C. mus } \\
\text { C. punctulatus } \\
\text { D. ensinfer } \\
\text { D. planidens }\end{array}$ & $\begin{array}{l}\text { Fruit, under canopy } \\
\text { Fruit, under canopy } \\
\text { Under canopy } \\
\text { Under canopy }\end{array}$ \\
\hline
\end{tabular}
Ischigualasto Provincial Park, San Juan, Argentina 
Table 4. Generalized linear models to evaluate the microhabitats used by ants in the Prosopis forests. "Microhabitat "Trunk bark" was included in the intercept. $* \mathrm{p} \leq 0.05$

\begin{tabular}{lcccc}
\hline Microhabitats & Estimate & $\begin{array}{c}\text { Standard } \\
\text { Error }\end{array}$ & Error & P \\
\hline (Intercept) & 2.0794 & 0.3536 & 5.882 & $4.06 \mathrm{e}-09^{\mathrm{a}}$ \\
Branches & -0.9808 & 0.6770 & -1.449 & 0.1474 \\
Dry riverbed & -2.0794 & 1.0607 & -1.961 & $0.0499^{*}$ \\
Fallen trees & -2.0794 & 1.0607 & -1.961 & $0.0499^{*}$ \\
Flowers & -2.0794 & 1.0607 & -1.961 & $0.0499^{*}$ \\
Fruits & -0.6931 & 0.6124 & -1.132 & 0.2577 \\
Inter canopy & -0.4700 & 0.5701 & -0.824 & 0.4097 \\
Leaves & -0.9808 & 0.6770 & -1.449 & 0.1474 \\
Seeds & -1.3863 & 0.7906 & -1.754 & 0.0795 \\
Trunk & -2.0794 & 1.0607 & -1.961 & $0.0499 *$ \\
Trunk bark galls & -1.3863 & 0.7906 & -1.754 & 0.0795 \\
Under canopy & -0.1335 & 0.5175 & -0.258 & 0.7964 \\
\hline
\end{tabular}

In Prosopis trees, ant species carried out several activities in different plant structures and microhabitats (Table 3). In these forests, the microhabitats with greater richness of ant species were trunk barks with 8 species and the area under the canopies with 7 species, respectively. These microhabitats were significantly different from the microhabitats with less ant species richness offered by Prosopis' trees as branches, fallen trees, flowers, trunks and dry riverbed, with one species on each one (Table 4). Camponotus species were the most commonly recorded on these trees, and this genus was seen foraging on flowers and galls or moving on flowers and branches in intercanopy and tree-shaded microhabitats. Dorymyrmex species were recorded on secretions and exudations of leaves and branches, collecting seeds and pieces of pods. Forelius species were observed on bare soil under the tree canopy (above the ground). Pogonomyrmex was observed collecting seeds from faeces deposited on bare ground and travelling in tree-shaded microhabitats (Table 3). In $R$. girolae and $B$. retama trees, ants exhibited lower variety of activities and less use of microhabitat (Table 3 ). The microhabitats more used in $R$. girolae were trunk barks and the area under canopies in $B$. retama (with 8 and 4 species, respectively).

\section{Discussion}

Even though the area under study is a hyper-arid desert, the overall species richness recorded in the native dryland forests of the IPP is, to our knowledge, the highest found for both the Monte Desert and Dry Chaco. Our study expands the pioneering list by Murúa et al. (1999), who found only 19 species on Prosopis spp. and B. retama trees in the Ischigualasto Provincial Park and Use Multiple Reserve of Valle Fértil, spite this later area has three times more precipitation than that of the IPP (Márquez 1999).

Ant species richness is usually correlated with primary productivity estimated on the basis of annual precipitation (Davidson 1977), and IPP comprises a hyper-arid area with scarce vegetation cover and low precipitation (Márquez et al. 2005). In the Man and Biosphere Reserve of Nacuñan (province of Mendoza), a protected area of the central plains and plateaus Monte Desert ecoregion, located 400 $\mathrm{km}$ southeaster from IPP and with three times more precipitation, Claver et al. (2014) found 27 ant species in an open forest of Prosopis flexuosa. Similarly, in the Sierra de Las Quijadas National Park (province of San Luis), a protected area located $300 \mathrm{~km}$ southern from IPP in the ecotone between the plains and plateaus Monte Desert and Dry Chaco ecoregions, with a higher precipitation and vegetation cover than IPP, Garcia and Quirán (2002) found only 23 species. On Prosopis ruscifolia (Grises.) trees in the Dry Chaco (province of Santiago del Estero), $300 \mathrm{~km}$ eastern form IPP and with a mean annual precipitation of 250-450 mm, Fuster (2012) found only 16 species.

Although more studies need to be carried out in order to explain the high richness found in this hyper-arid area, the combination of capture methods used in the present study could explain this. Several authors suggest that using more than one capture method has proved to be more useful in order to obtain a more complete list of ant species (Lutinski et al. 2013). However, ant species richness in the IPP is within the reported range for other desert and semi-desert areas of the world. For example, Rios-Casanova et al. (2004) found 28 species in a deciduous tropical forest; Bestelmeyer and Schooley (1999) found 39 species on a site dominated by trees such as ironwood (Olneya tesota A. Gray, Fabaceae) in the southern portion of the Sonoran Desert; Rojas and Fragoso (2000) reported 32 species for a site with shrubs and grassland in the Chihuahuan Desert, and Morton (1993) reported 33 ant species for North American arid shrubs.

The dominance of the subfamily Myrmicinae, followed by Dolichoderinae, and the low representation of Dorylinae are consistent with previous findings at nearby sites (Murúa et al. 1999; Garcia and Quirán 2002; Fuster 2012; Claver et al. 2014). The dominance of Myrmicinae is a consistent pattern found in other arid and semiarid regions of the world (Andersen and Yen 1992; Bestelmeyer and Schooley 1999; Rojas and Fragoso 2000; Ribas et al. 2003; RiosCasanova et al. 2004; Pérez-Sanchez et al. 2012). Myrmicinae and Dolichoderinae have more mutualistic associations with plants (Brown 1973). The fact that $N$. diana was found in $R$. girolae trees agrees with Rojas and Fragoso (2000), who mention that this subfamily contains species usually associated with forests. Though, we cannot reach an actual conclusion since only one individual of this species was found.

Despite the sampling being concentrated on the trees, the most relevant functional group was that of hot-climate specialists with 10 species. This functional group comprise well arid-adapted species with morphological, physiological and behavioural specializations (sensu Andersen 1995). These characteristics allow them to withstand high temperatures and low humidity, and to use open environments with scarce or low vegetation cover, which they even use to build their nests (Cuezzo 1999). This finding highlights the ability of this group to use also highly shaded forest habitats. For example, Dorymyrmex species were observed both under and within the canopy of the three types of forests, whereas Pogonomyrmex species were observed collecting seeds from faeces lying on bare 
soil as in Vélez et al. (2015) and moving in tree-shaded microhabitats. These species have been also characterized as thermophilics by Bestelmeyer (2000) and as keystone seed dispersers of myrmecochorous plants by ArandaRickert and Fracchia (2012). Truly arboreal ant species belonging to the genus Cephalotes was only found on Prosopis spp. trees. The low presence of exclusive arboreal species is consistent with the common trend observed in arid areas (Andersen and Yen 1992).

On the other hand, cryptic, army ant, and opportunistic species were the least represented groups. Cryptic and army ants were scarce likely because they have highly specific habitat requirements (e.g. a deeper litter layer) and they are infrequently found in arid lands (Rojas and Fragoso 2000; Hoffmann and Andersen 2003). This would explain why only one worker of the predator army ants $N$. diana, occurred in our study site. Army ant genera occur in regions of northern Argentina with higher annual precipitation, and consequently higher biomass and litter cover (Fuster 2012), with the only exception of the Neyvamyrmex genera that reaches higher latitudes. Interestingly, this finding represents the southernmost record known at present for $N$. diana. Curiously, the dark rover ant, Brachymyrmex patagonicus, considered opportunistic in its native range in the Neotropic, is a dominant species in the Gulf Coast region of the United States, where it has been introduced (MacGown et al. 2007).

Only two species of leaf-cutter ants (Attini functional group) were found in Prosopis spp. and $R$. girolae forests. They were observed using branches, leaves, fruits and seeds of Prosopis and moving them under their canopy; whereas in $R$. girolae forest, they were only observed on the trunk bark and under its canopy. The species of the Attini group are epigaeic ants that use plant matter and detritus to cultivate fungus (Bestelmeyer and Schooley 1999). Leaf cutting ants cut plant parts that they use as substrate for the fungus they cultivate and have been shown to contribute to seed dispersal of certain forest species (Silva et al. 2007).

Prosopis spp. trees harbour the highest number of ant species. These trees have a broad and densely branched canopy with long thorns, extrafloral nectaries, and galls like other Prosopis species (Burkart 1952). R. girolae and $B$. retama trees are structurally simpler than Prosopis species, both of them are thornless, whereas $R$. girolae is aphyllous (Hadad et al. 2014) and B. retama is almost aphyllous (Palacios and Hunziker 1984), and up today, we have never seen galls on either species (S. Giannoni and E. Amatta, pers. obs.). The low richness of $B$. retama could be explained by the fact that it is smaller than the other two tree species, and also by the fact that it has the simplest structure. For example, a sparsely developed bark, and as it is a tree strongly adapted to xeric conditions, a less developed leaf litter layer which makes it harbor less vegetation under its canopy providing only scarce microhabitats to ants. The highest ant richness found in the Prosopis spp. forest could be due to this tree higher leaf density, or canopy complexity, as it was also found in other desert forests (Vasconcelos et al. 2008).
In summary, 33 ant species belonging to 13 genera were recorded in the three types of forests, with Prosopis spp. having the highest species richness. Twenty-four species represent new records for the province of San Juan, 17 species represent new records for the Monte Desert and Dry Chaco ecoregions, and 30 new species for the IPP. Our study contributes to a better knowledge of ant species inhabiting forests in drylands of central-western Argentina and alert about the importance to preserve Prosopis spp. forests, which harboured most ant diversity.

\section{ACKNOWLEDGEMENTS}

We thank the staff of Ischigualasto Provincial Park for providing all the necessary facilities during fieldwork. We thank Rebecca Lomas-Milne (Swansea University), Nelly Horak and Gabriela Rossetti for helping us to improve the writing of the manuscript. We also thank Andrés Sánchez Restrepo for helping to identify some ant species; Tomás González for providing the map and photos of the three forests. We are grateful for the help received from the members of INTERBIODES (Interacciones biológicas del desierto) for providing constructive and useful comments that improved the version of this article. Funding was provided by Proyecto Bosque Nativo (Resolution $\mathrm{N}^{\circ}$ 0441).

\section{REFERENCES}

Acebes P, Traba J, Peco B, Reus ML, SM Giannoni, Malo JE. 2010. Abiotic gradients drive floristic composition and structure of plant communities in the Monte Desert. Revista Chilena de Historia Natural 83: 395-407.

Andersen AN, Yen AL. 1992. Canopy ant communities in the semi-arid mallee region of north-western Victoria. Australian J Zool 40: 20514.

Andersen AN. 1995. A classification of Australian ant communities based on functional groups which parallel plant life-forms in relation to stress and disturbance. J Biogeogr 22: 15-29.

Aranda-Rickert A, Fracchia S. 2012. Are subordinate ants the best seed dispersers? Linking dominance hierarchies and seed dispersal ability in myrmecochory interactions. Arthropod Plant Interact 6: 297-306.

Safriel U, Adeel A. et al. 2005. Dryland systems. In: El-Kassas M, Ezcurra E (eds.). Assessment Millennium Ecosystem, Ecosystems and Human Well-Being: Current State and Trends. Island Press, Washington, DC.

Bestelmeyer BT. 1997. Stress tolerance in some Chacoan dolichoderine ants: implications for community organization and distribution. J Arid Environ 35: 297-310.

Bestelmeyer BT. 2000. The trade-off between the thermal tolerance and behavioural dominance in a subtropical South American ant community. J Anim Ecol 69: 998-1009.

Bestelmeyer BT, Wiens JA. 1996. The effects of land use on the structure of ground-foraging ant communities in the Argentine Chaco. Ecol Appl 6: 1225-1240.

Bestelmeyer BT, Schooley RL. 1999. The ants of the southern Sonoran Desert: community structure and the role of trees. Biodiv Conserv 8: 643-657.

Bolton B. 2013. AntWeb: Ants of Bolton World Catalog. www.antweb.org.

Brown WL. 1973. A comparison of the Hylean and Congo-West African rain forest ant Faunas. In: Meggers BJ, Ayenson ES, Duckworth WD (eds). Tropical Forest Ecosystems in Africa and South America: A comparative review. Smithsonian Institution Press, Washington, D.C. 
Brown A, Martinez Ortiz U, Acerbi M, Corcuera J. 2006. La Situación Ambiental Argentina. Fundación Vida Silvestre Argentina, Buenos Aires, Argentina.

Burkart A. 1952. Las leguminosas argentinas: silvestres y cultivadas. Acme Agency S.R.L. Buenos Aires, Argentina.

Burkart R, Bárbaro NO, Sánchez RO, Gómez DA. 1999. Ecorregiones de la Argentina. Administración de Parques Nacionales, Buenos Aires, Argentina.

Cabrera A, Willink A. 1980. Biogeografía de América Latina. 2nd ed. Ser. Biol. Monogr. No. 13. - Secretaría General de la Organización de los Estados Americanos, Progr. Reg. Desarrollo. Cient, y Tecnol., Washington, DC

Calcaterra LA, Cuezzo F, Cabrera SM, Briano JA. 2010. Ground ant diversity in the Ibera Nature Reserve, the largest wetland of Argentina. Ann Entomol Soc Amer 103: 71-83.

Campos CM, Velez S. 2015. Almacenadores y frugívoros oportunistas: el papel de los mamíferos en la dispersión del algarrobo (Prosopis flexuosa DC) en el Desierto del Monte, Argentina. Ecosistemas 24: 28-34

Campos VE, Cappa FM, Fernandez-Maldonado V, Giannoni SM. 2016. Using remotely sensed data to model suitable habitats for tree species in a desert environment. J Veg Sci 27: 200-210.

Campos VE, Fernández-Maldonado V, Balmaceda P, Giannoni SM. 2017. Richness of plants, birds and mammals under the canopy of Ramorinoa girolae, an endemic and vulnerable desert tree species. Bosque 38: 307-316.

Campos VE, Gatica GM, Cappa FM, Giannoni SM, Campos CM. 2018. Remote sensing data to assess compositional and structural indicators in dry woodland. Ecol Indicat 88: 63-70.

Chacoff NP, Aschero V. 2014. Frequency of visits by ants and their effectiveness as pollinators of Condalia microphyllaCav. J Arid Environ 105: 91-94.

Claver S, Silnik SL, Campón F. 2014. Response of ants to grazing disturbance at the Central Monte Desert of Argentina: community descriptors and functional group scheme. J Arid Land 6: 117-127.

Cuezzo F. 1999. Nuevas citas de hormigas de las tribus Dacetini y Basicerotini (Hymenoptera: Formicidae) para la República Argentina. Revista de la Sociedad Entomológica Argentina 58: 3-4.

Dalmasso AD, Llera JA. 1996. Contenido de cera en relación al diámetro de ramas de Bulnesia retama en Ampacama, Caucete, San Juan. Multequina 5: 43-48.

Davidson DW. 1977. Species diversity and community organization in desert seed-eating ants. Ecology 58: 711-724.

De Fina AL, Giannetto F, Sabella LJ. 1962. Difusión geográfica de cultivos índices en la provincia de San Juan y sus causas. Publicación $\mathrm{N}^{\circ}$ 80. Instituto de Suelos y Agrotecnia e INTA, Buenos Aires, Argentina

Demaio P, Karlin U, Medina M. 2002. Árboles nativos del centro de Argentina. Editorial Literature of Latin America, Buenos Aires, Argentina.

Emery C. 1888. Formiche della provincia di Rio Grande do Sûl nel Brasile, raccolte dal dott. Hermann von Ihering. Bullettino della Società Entomologica Italiana 19: 352-366.

Emery C. 1894. Camponotus sexguttatus Fab. e C. sexguttatus Sm. et auct. Bollettino dei Musei di Zoologia ed Anatomia Comparata della Reale Università di Torino 9: 1-4

Emery C. 1906. Studi sulle formiche della fauna neotropica. XXVI. Bullettino della Società Entomologica Italiana 37: 107-194.

Forel A. 1886. Espèces nouvelles de fourmis américaines. Annales de la Société Entomologique de Belgique 30: 38-49.

Forel A. 1903. Mélanges entomologiques, biologiques et autres. Annales de la Société Entomologique de Belgique 47: 249-268.

Forel A. 1907. Nova speco kaj nova gentonomo de formikoj. Internacia Scienca Revuo 4: 144-145.

Forel A. 1911. Ameisen des Herrn Prof. v. Ihering aus Brasilien (Sao Paulo usw.) nebst einigen anderen aus Südamerika und Afrika (Hym.). Deutsche Entomologische Zeitschrift 285: 312.

Forel A. 1912. Formicides néotropiques. Part V. me sousfamille Dolichoderinae Forel. Mém Soc Entomol Belg 20: 33-58.

Forel A. 1912. Formicides néotropiques. Part II. 3me sous-famille Myrmicinae Lep. (Attini, Dacetii, Cryptocerini). Mémoires de la Société Entomologique de Belgique 19: 179-209.

Forel A. 1913. Fourmis d'Argentine, du Brésil, du Guatémala, de Cuba reçues de M. M. Bruch, Prof. v. Ihering, Mlle Baez, M. Peper et M. Rovereto. Bulletin de la Société Vaudoise des Sciences Naturelles 49 203-250.
Fuster A. 2012. Especies de hormigas asociadas a Prosopis ruscifolia Griseb en ambientes salinos del Chaco Semiárido. Quebracho 20: 2938

Gallardo A. 1916. Las hormigas de la República Argentina. Subfamilia Dolicoderinas. Anales del Museo Nacional de Historia Natural de Buenos Aires 28: 1-130.

García M, Quirán EM. 2002. Lista preliminar de formícidos (Insecta: Hymenoptera) del Parque Nacional Sierra de las Quijadas, San Luis, Argentina. Gayana 66: 83-84.

Ginzburg O, Whitford WG, Steinberger Y. 2008. Effects of harvester ant (Messor spp.) activity on soil properties and microbial communities in a Negev Desert ecosystem. Biol Fertil Soils 45: 165-173.

Hadad M, Almirón M, Scaglia J. 2014. Estructura de un bosque de Ramorinoa girolae (Fabaceae), en la Sierra de Pie de Palo, San Juan (Argentina). Boletín Sociedad Argentina Botánica 49: 283-292.

Hanisch PE, Calcaterra LA, Leponce M, Achury R, Suarez AV, Silva RR, Paris C. 2015. Check list of ground-dwelling ant diversity (Hymenoptera: Formicidae) of the Iguazú National Park with a comparison at regional scale. Sociobiol 62: 213-227.

Hoffmann B, Andersen A. 2003. Responses for ants to disturbance in Australia, with particular reference to functional groups. Austral Ecol 28: 444-464.

Hölldobler B, Wilson EO. 1990. The Ants. The Belknap Press of Harvard University Press, Cambridge.

Kusnezov N. 1978. Hormigas Argentinas: claves para su identificación. Miscelanea No. 61, Tucumán, Argentina.

Labraga JC, Villalba R. 2009. Climate in the Monte Desert: past trends, present conditions, and future projections. J Arid Environ 73: 154163.

Lutinski JA, Lutinski CJ; IOP S, Mello-Garcia FR. 2013. Evaluation of an ant sampling protocol (Hymenoptera: Formicidae) in three modified environments located inside an austral Atlantic Forest area of Brazil. Ecología Austral 23: 37-43.

MacGown JA, Hill JG, Deyrup MA. 2007. Brachymyrmex patagonicus (Hymenoptera: Formicidae), an emerging pest species in the southeastern United States. Florida Entomol 90: 457-464.

MacKay WP. 1991. The role of ants and termites in desert communities. In: Polis GA (ed.). The Ecology of Desert Communities. University Arizona Press, Tucson, AZ

Márquez J. 1999. Las áreas protegidas de la provincia de San Juan. Multequina 8: 1-10

Márquez J, Martinez Carretero E, Dalmasso A, Pastrán G, Ortiz G. 2005. Las áreas protegidas de la provincia de San Juan (Argentina) II. La vegetación del Parque Provincial Ischigualasto. Multequina 14: 1-27.

Mayr G. 1868. Formicidae novae Americanae collectae a Prof. P. de Strobel. Annuario della Società dei Naturalisti e Matematici, Modena 3: 161-178.

Mayr G. 1887. Südamerikanische Formiciden. Verhandlungen der Kaiserlich-Königlichen Zoologisch-Botanischen Gesellschaft in Wien 37: 511-632.

Moffett, MW. 2012. Supercolonies of billions in an invasive ant: What is a society?. Behav Ecol 23(5): 925-933.

Morton SR. 1993. Determinants of diversity in animal communities of arid Australia. In: Riclefs RE, Schluter D (eds). Species diversity in ecological communities. Historical and Geographical Perspectives. University of Chicago Press, Chicago, IL.

Murúa F, Cuezzo F, Acosta JC. 1999. La fauna de hormigas del Gran Bajo Oriental del departamento Valle Fértil, San Juan, Argentina. Revista Sociedad Entomológica Argentina 58: 135-138.

Palacio EE, Fernández F. 2003. Claves para las subfamilias y géneros. In: Fernández $\mathrm{F}$ (ed). Introducción a las hormigas de la región Neotropical. Instituto de Investigación de Recursos Biológicos Alexander von Humboldt, Bogotá, Colombia.

Palacios RA, Hunziker JH. 1984. Revisión taxonómica del género Bulnesia (Zygophyllaceae). Darwiniana 25: 299-320.

Pérez-Sánchez AJ, Lattke JE, Viloria AL. 2012. Composición y estructura de la fauna de hormigas en tres formaciones de vegetación semiárida de la península de Paraguaná, Venezuela. Interciencia 37: 506-514.

Perosa M, Rojas, F, Villagra, P, Tognelli, MF, Carrara, R, Alvarez, JA. 2014. Distribución potencial de los bosques de Prosopis flexuosa en la Provincia Biogeográfica del Monte (Argentina). Ecología Austral 24: 238-248.

Ribas CR, Schoereder JH, Pic M, Soares SM. 2003. Tree heterogeneity, resource availability, and larger scale processes regulating arboreal ant species richness. Austral Ecol 28: 305-314 
Rios-Casanova L, Valiente-Banuet A, Rico-Gray V. 2004. Las hormigas del valle de Tehuacán (Hymenoptera: Formicidae): una comparación con otras zonas áridas de México. Acta Zoológica Mexicana 20: $37-$ 54.

Roger J. 1863. Die neu aufgeführten Gattungen und Arten meines Formiciden-Verzeichnisses nebst Ergänzung einiger früher gegebenen Beschreibungen. Berliner Entomologische Zeitschrift 7: 131-214.

Rojas P, Fragoso C. 2000. Composition, diversity, and distribution of a Chihuahuan Desert ant community. Mapimí, México. J Arid Environ 44: 213-227.

Santschi F. 1916. Formicides sudaméricains nouveaux ou peu connus. Physis (Buenos Aires) 2: 365-399.

Santschi F. 1923. Pheidole et quelques autres fourmis néotropiques. Annales de la Société Entomologique de Belgique 63: 45-69.

Silva PS, Leal IR, Wirth R, Tabarelli M. 2007. Negative impact of leafcutting ants (Atta sexdens) on tree recruitment of Protium heptaphyllum (Burseraceae) through seed aggregation and seedling cutting. Revista Brasileira de Botanica 30: 553-560.

Smith F. 1858. Catalogue of hymenopterous insects in the collection of the British Museum. Part VI. Formicidae. British Museum, London.
Spinola M. 1851. Compte rendu des Hyménoptères inédits provenants du voyage entomologique de M. Ghiliani dans le Para en 1846. Extrait des Mémoires de l'Académie des Sciences de Turin 13: 3-78.

Vasconcelos HL, Leite MF, Vilhena J, Lima AP, Magnusson WE. 2008. Ant diversity in an Amazonian savanna: relationship with vegetation structure, disturbance by fire, and dominant ants. Austral Ecol 33: 221-231.

Vélez S, Chacoff NP, Campos CM. 2015. Seed predation and removal from faeces in a dry ecosystem. Basic and Applied Ecol 17: 145-154.

Villagra RE, Defosse GE, Del Valle HF, Tabeni S, Rostagno M, Cesca E, Abraham E. 2009. Land use and disturbance effects on the dynamics of natural ecosystems of the Monte Desert: Implications for their management. J Arid Environ 73: 202-211.

Whitford WG. 2002. Ecology of desert systems. Academic Press, Elsevier Science Imprint, San Diego, California.

Whitford WG, Barness G, Steinberger Y. 2008. Effects of three species of Chihuahuan Desert ants on annual plants and soil properties. J Arid Environ 72: 392-400. 